STATE OF ILLINOIS

DEPARTMENT OF REGISTRATION AND EDUCATION

DIVISION OF THE

NATURAL HISTORY SURVEY

STEPHEN A. FORBES, Chief

\begin{tabular}{lll}
\hline Vol. XVII. BULLETIN & Article IV.
\end{tabular}

\title{
The Plankton of Lake Michigan
}

\author{
BY
}

SAMUEL EDDY



PRINTED BY AUTHORITY OF THE STATE OF ILLINOIS

URBANA, ILLINOIS

November, 1927 
STATE OF ILLINOIS

DEPARTMENT OF REGISTRATION AND EDUCATION

A. MI. SHELTON. Director

\section{BOARD OF}

\section{NATURAL RESOURCES AND CONSERVATION}

\section{A. M. Sieltox, Chairman}

Wirlan Trituase, Riology

Hexir C. Cowles, Forestry

Edsox S. Bastix. Geology

Wirdia A. Nores. Chenistry
JoHN W. ALvord. Engineering Cinarles M. Thompson, Representing the President of the University of Illinois

THE NATURAL HISTORY SURVEY DIVISION

Stephex A. Fondes. Chief

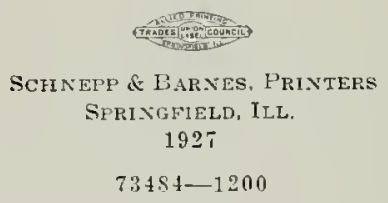


Illinois State Natural History Survey Bulletin Vol. Trtl Ant IV.

\section{ERRATA}

zes 208, 211, 214, 219-for Bacellariaceae read Bacillariaceae.

se 209. middle of table-for oligactus read oligactis.

5e 211, fifth line in table-for Aphanotheca read Aphanothece.

;e 213 , first line in table-for oligactus read oligactis.

215. fourth line in table-for acuminata Ehr. read acuminatum (Kutz.) Cl.

218, sixth paragraph-for Aphanotheca read Aphanothece.

e 220, fifth paragraph-for acuminata read acuminatum.

224, fourth line from botton--for Pandorin read Pandorina.

Omit last line and read Traverse Bay region.

228. fifth line from bottom- for Antario read Ontario. 


\section{'THE PLANITON OF' LAKE MICHIGAN}

\section{SAMUEL EDDY}

The minute organisms constituting the plankton of the Great Lakes have becu studied previously more in connection with investigations of their inter-biotic relations rather than from the primary aspect of the plankton. Perhaps the largest amount of work has been done by investigators who were interested chiefly in the relation of the plankton to the white-fish industry. This is one of the most important phases of plankton work, because the white-fish as well as other fishes of the Great Lakes is rependent upon the plankton for food in its early life (Forbes, 188.3)a fact which has made the study of plankion and plankton production most valuable. Other investigators have made fragmentary studies of the plankton of the Great Lake- for taxononic purposes : Kellicott. Jennings, and others, for example, devoted their attention to the occurrence of certain groups of organisms and to the number and description of species in those groups as found in the (reat Lakes.

The chief purposes of this paper are: (1) to present a general picture of the plankton of Lake Mlichigan. (?) to determine the relative abundance of its constituent organisns. and (3) to incorporate and summarize the facts now known relating to the plankton of the Great Lakes.

Very little work of a quantitative nature has been published on this subject within the last twenty years. Previons to this period a number of qualitative investigations were nacle on the plankton of Lake Erie, Lake St. Clair, Lake Mlichigan, and Lake Superior : and a very important work of both quantitative and qualitative character was done on Lake Michigan in the Traverse Bay region by the Michigan Fish Cimmission (Nard, 1896). In the latter investigations. which covered both bottom and plankton organisms, the gross quantity of the plankion was estimated from silk-net tows. and some idea of the general claracter of the plankton was obtained from the relative abundance of the constituent organisms.

\section{METHODS AND MATERIALS}

The data for the present paper were obtained from two series of co!lections made from Lake Michigan in $18 x ;-1$ sist and 1!?6-19:3. Fifty silk-net tows (Table I) were made by the llinois State Laboratory of Natural History from November, 188 i to November. 1888 from the breakwater at Chicago. Quantitative silk-net and filter-paper collections (Table II) were marle October 16-1\%, 19:6 at Indiana State Dunes Park and 11 ichigan City, Indiana, and near Sawyer. Michigan. Quantitative collec- 
tions (Table III) were also made May 14-15, 1927 at Dunes Park and Gary, Indiana, and July 10, 192: at Chicago. Illinois. All of the:e were surface tows near the shore, so that the material in this paper relates only to surface and in-shore conditions. No investigation has been reported on the plankton or the conditions in the central area of the lake.

The material of the older series of collections, which had been preserved in formalin and glycerin, was found to be in excellent condition. Unfortunately, the accession numbers on some of these collections had become illegible, so that it was impossible to secure definite information in regari to the montlis of January, February, and March of the year 18s8. The collections which were assumed to cover these months showed very little variation in the constituent organisms from those of the other months.

\section{Puysical Conditions}

Lake Michigan offers a very stable habitat for the production of plankton. Because of its large size and the lack of strong currents, the physical conditions of the water vary but slightly from year to year; therefore, the same constituent organisms may be expected in the plankton over a long period of time. Forbes $(18 \times 3)$ found that the conditions of life in Lake Michigan were remarkably uniform throughout the seasons and from year to year and that both plant and animal life exhibited there a regularity and stability in remarkable contrast to their fluctuations in smaller bodies of water and on the surrounding land. There was little change, he found, in the relative number of individuals of the various species or in the absolute number of each. Shelford (Ward and Whipple, 1918) pointed out that Lake Michigan, being a large and deep lake, had none of the seasonal temperature changes extending to the deeper parts. Consequently, as only the surface temperature fluctuates, one would expect the deeper portions to exert a more stabilizing influence on the surface waters than would be found in the waters of more shallow lakes. The stability of the lake as a biotic factor is strikingly demonstrated by our comparisons of data covering a period of forty years, for little or $n 0$ change bas occurred in the composition of the plankton over this long period. Many of the constituent species, though showing slight seasonal variations, are rather constantly abundant throughout the year.

The south end of Lake Nichigan is composed of gently-sloping sand beaches exposed to considerable wave action. In the northern portion of the lake there is some rocky shore line. Areas of mud flats and aquatic vegetation are rare. All these conditions are characteristic of a primitive lake. There is little variation in water level or shore line from year to year, and overflow conditions ate practically unknown. Cooley (1913) gives the following figures covering the water level for the years 1860 1913:

Greatest yearly range of Lake Michigan...... $1.94 \mathrm{ft}$.

Least " "

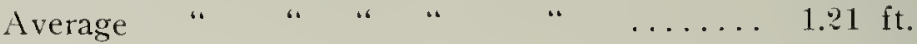


At the south cul the sandy character of the heaches and the strong wave ation prevent the growth of vegetation with its conserfuent influence on the conditions and life of the water. I'ractically all the plankton, therefore, must originate within the limnetic area. Shallow breeding areas such as Kofoid (1!08) found in the hackwaters of lllinois River are practically unknown. Adventitions species so common in the plankton of the sline and bottom areas of rivers and shallow lakes are rare.

Stable conditions are insured still further by the extremely slow removal and renewal of the water in the lake. Speaking generally, Ward (Ward and Whipple, 1918) stated that great depth in a body of water and a large inflow in proportion are unfavoralsle to the alumdant prorluction of plankton, and Ward (1896i) computed that there is a change of about oneeigh icth of the entire volume of I alke Michigan in one year. In other words, there are no extensive outflows to upset the conclitions of life in this lake.

The suspended organic matter and silt so common during overflows in rivers and other plankton-learing waters-and so detrimental to the production of plankton organisms-seem to he at a minimum in Lake Michigan. (The turbidity was not recorded when the collections were made, lut it never seemed to be very high.) . Ill things considered, the conditions for plankton production in Lake Miehigan approach those of the sea as neal as do those of any loxly of freshwater.

\section{General CHARACTER}

The gross bulk of the plankton in the water, determined from the collections made in 1!9(i-1!2i. is quite large. Ward (1s!) reported that the flankton in the upper two meters in the Traverse Bay region tanged from s.!) to $14.12 \mathrm{c}$. c. per cubic meter, and that the abundance of the flankton gradually diminished in the lower levels. His data were obtained by allowing the silk-net collections to settle in a grarluaterl cylinder and computing the volume of the planliton per cubic meter. The same method when used on the recent collections showed an even greater bulk for the surface plankton. The collections of ()ctober. 1926, averaged 10 c. c., and those of May. 19?2, 10 c. c. per cubic meter. Some differences in bulk may be due to time. locality. and scasonal variations. The heavy bulk of the May, 19:5, plankton may le due to a spring condition, as Ward's collections were made in summer.

In general, the plankton of Lake Michigan is that which characterizes large and cleep lakes. Its specific character consists principally of diatoms of the genera Astcrionclla, Striatlla (Tabellaria), and Fragilaria. Limnetic afgac are not very conspicuous. Zooplanlitonts are generally scarce in numbers, but always present to some extent. In the 18s\%-1888 collections the zonplanktonts, particularly those of the larger sort, were much more abunclant than in the recent collections and sometimes comprised nearly half the total number of organisms present. The absence of the smalier organisms in the older series makes it reasonable to as- 
sume that a coarser net must have been used, which would account for the loss of many of the smaller organisms and for the relative abundance of the larger forms.

As quantitative methods were not used in making the 188:-18ss collections, it was impossible to calculate the total volume of plankton at any time during that period. Qualitatively, however, the older series was very similar to the recent series.

At all times in the silk-net collections, the phytoplanktonts greatly outnumbered the zooplanktonts: the latter, however, made up for their smallness in numbers by their inuch larger individual size. Because of their spines and other peculiarities of shape, the plant species actually occupied a great deal less space than they seemed to at first glance, or than their numbers would indicate. Careful measurements, with an ocular micrometer, of the average actual bulk of the various silk-net organisms showed that the zooplanktonts, although present in much smaller numbers than the plant species, often comprised nearly one-half the total bulk. Considerable variation of this ratio between the animal and plant constituents was shown in different collections, depending on seasonal and other factors. This ratio would not apply to the total plankton of the lake, because not enough data were obtained in regard to the smaller organisms (nannoplankton), some of which escaped through the net but were found in the few filter-paper collections.

In all, 119 species were found, most of which were typical plankton species. More data on the nannoplankton would undoubtedly greatly increase this number. Sixty of these species were phytnplanktcnts and fifty-nine were zooplanktonts. This is only about onefifth of the total number of the species listed in the various reports of previous investigators as accurring in the waters of the Great Lakes. Of the 66 species occurring in our $188 \%-1888$ collections, $1 \%$ (at least three of which were adventitious) did not occur in our recent collections; most of these were never abundant and could have been easily lost in the later collections. Of the 102 species occurring in our 1926192: collections, 53 were not observed in the earlier collections: these were either rare or, as previously mentioned, were so small as to escape through the meshes of the net. Many species of algae which were not noted in the earlier series showed up in the recent series, though none of them were abundant. There is no evidence that any of the missing species did not exist in both periods. Anyone familiar with the methods of plankton study can easily understand how some of the smaller organisms by their scanty distribution can easily escape collection and observation. The t9 species which were common to both periods were ustually the larger and most abundant organisms.

A rich diatom flora predominated in all the collections, the same species occurring in both periods with few exceptions. Those species which were most abundant in the recent series appeared in the same proportions in the earlier series. 
The same species of copepods occurred in both periods with the notable exception of Efischura lacustris Forbes, which was abundant in the early collections but did not appear at all in the recent ones. The same species of claducerans were scattered throughout both series. The Protozoa and Rotifera, never abundant, were limited to a few common species occurring in most of the collections, and as they are hard to preserve for identification not enough good deterninations conld be made of most of them to estal)lish their distribution.

\section{SEASONIL ASIECT}

The data are not extensive enough to justify any delinite statenent of seasonal variations in the bulk of the plankton, although the fall collections of 1 !n: showed only one-fouth the lutk of the spring collections of $192 \%$. Seasonal variations in constituent species were noticeably lacking. the dominant diatoms rumning alnust nuniformly through the cof-

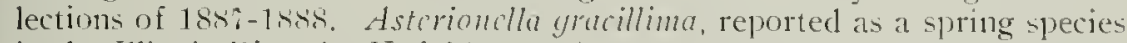
in the Illinois River by Kofoid (190s), 1 as abundant throughout the different months, as also were Lysiyomimm (Mclosira). Strialda (Tabd. laria). Suncdra, and Frugilaria. Other less abundant diatoms generally appeared irregularly in the collections. Forbes (1xisi) concluded, from his own observations and those of B. W. Thomas over a period of sixteen years. that there was little change in the constituent organisms in Lake Michigan from one season to another. althongh he noted a sl ght increase in number of species in the spring and summer nonths. In the 18 is-1,888 collections, the zooplanktonts showed a decided decrease in the colder months, being almost entirely absent in the collections of December and in those attriluted to Jannary. February, and March.

\section{Genteril Distribution}

A fairly miniform distribution of the plankton of Lake Mlichigan is to be expected, and very little difference has been noticed in the specific character of the plankton at different points. The off-shore waters of Lake Mlichigan are fairly well mixed by circulation; currents sweep southward on the west side, turn at the sonth end, and flow northward on the east side (Harrington, 1895), so that the water bearing the plankton at Chicago is, a few days later, off Michigan City. Incliana.

In all the collections examined, the exact number of organisms was never the same, and absolnte uniformity has never been reported in plankton investigations. A tendeney to swarm is indicated by the variations in abundance in all collections. Reighard (1s!) found evidence of plankton swarming in Lake St. Clair. Forbes (18.83) fonnd that the plankton was not equally distributed throughout the water and was more lense off the mouths of rivers. These variations. however. were not usually as great as those between different habitats or seasons. 





ปั่

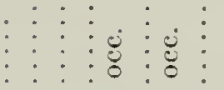

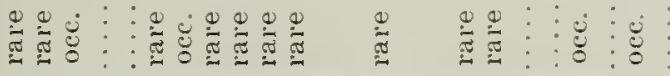

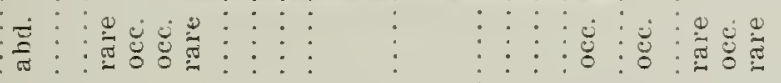

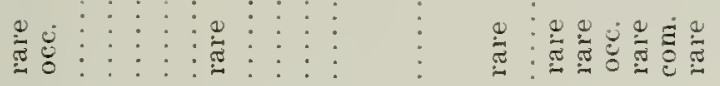

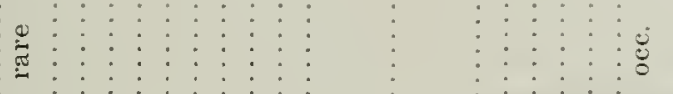

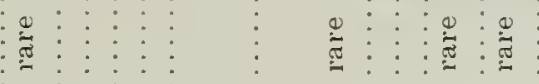

望

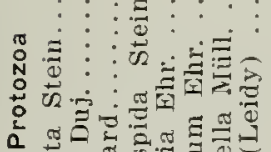

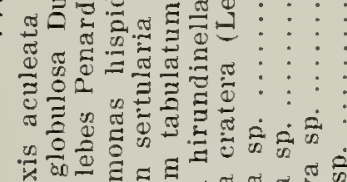
का

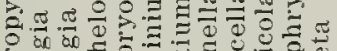




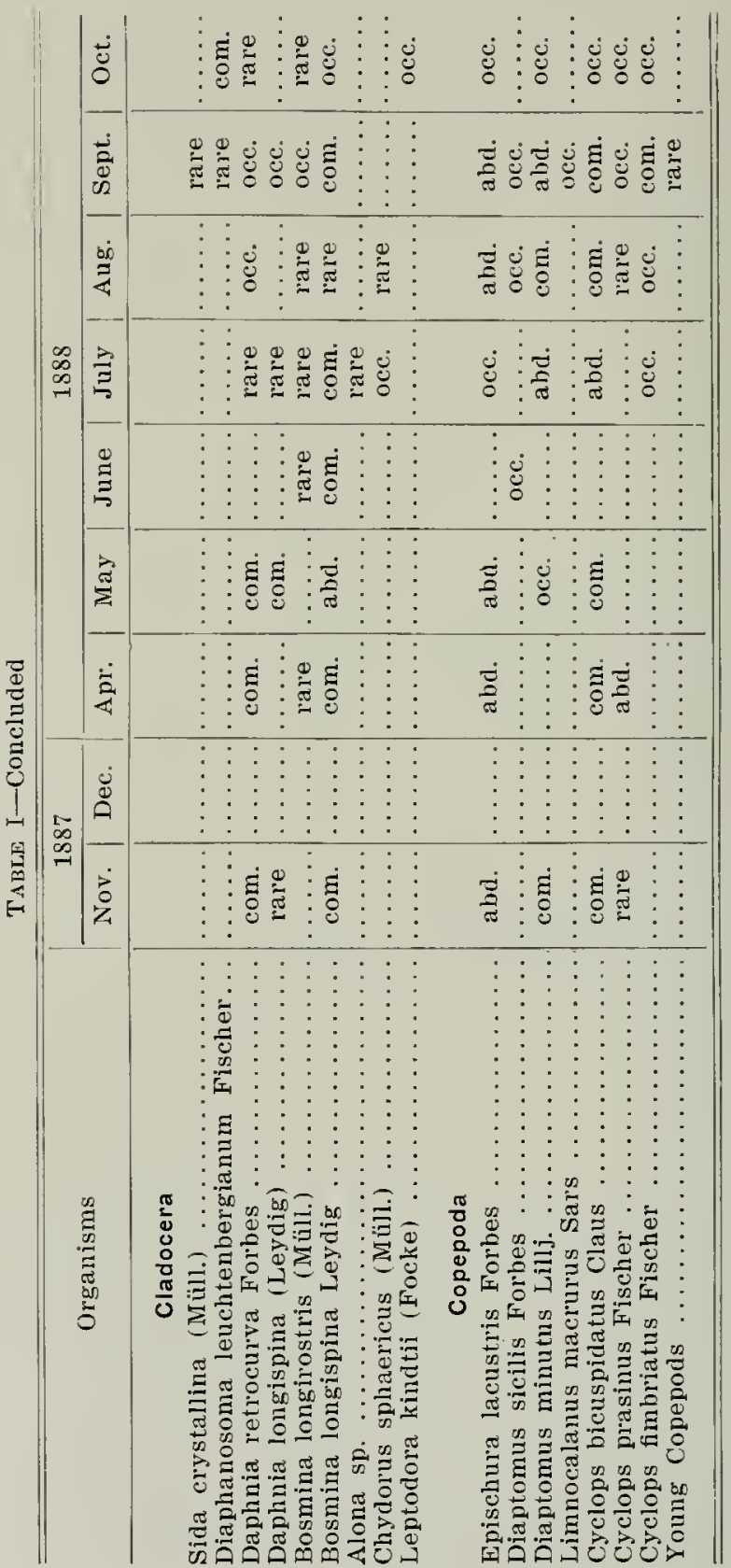




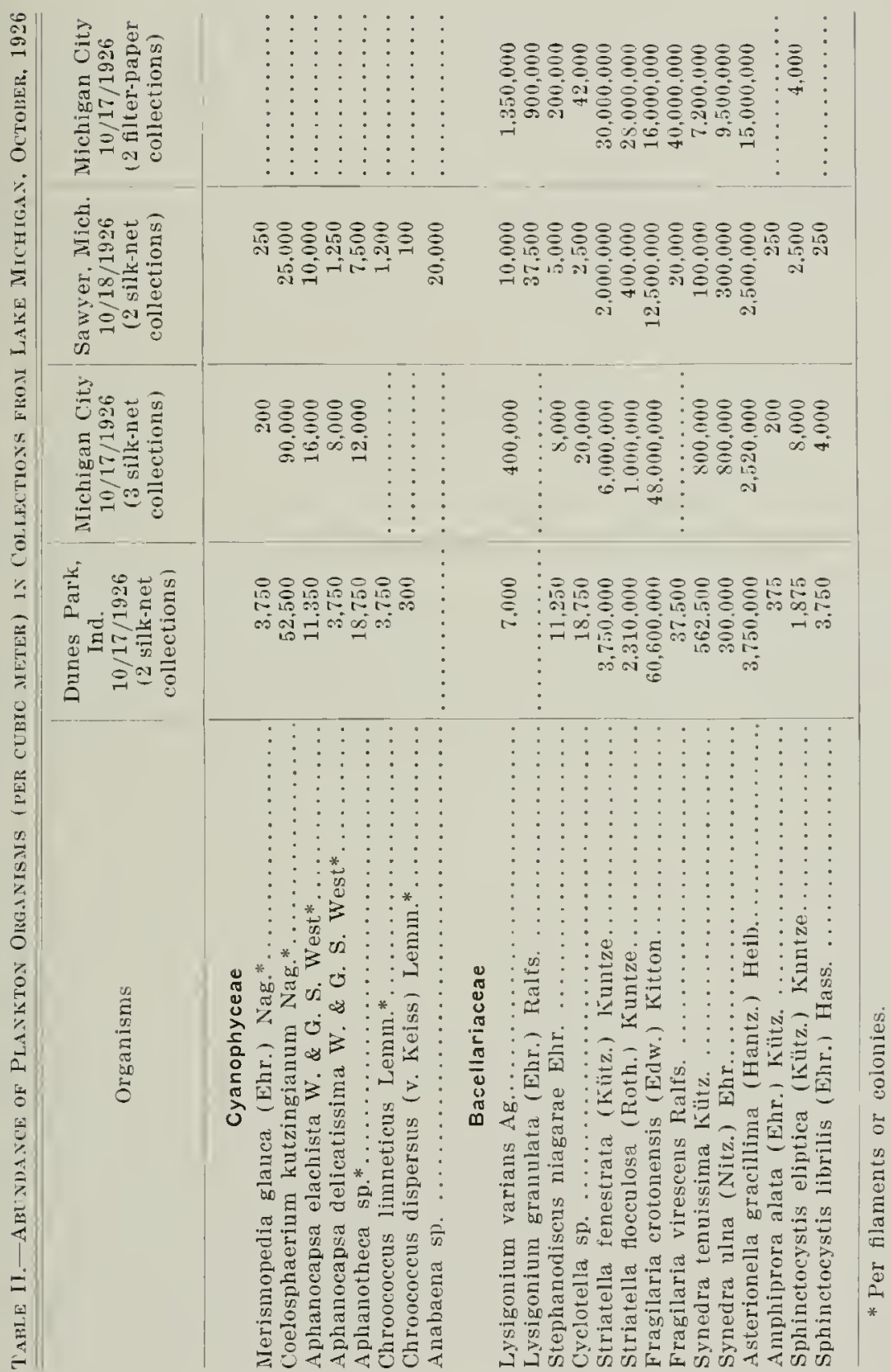









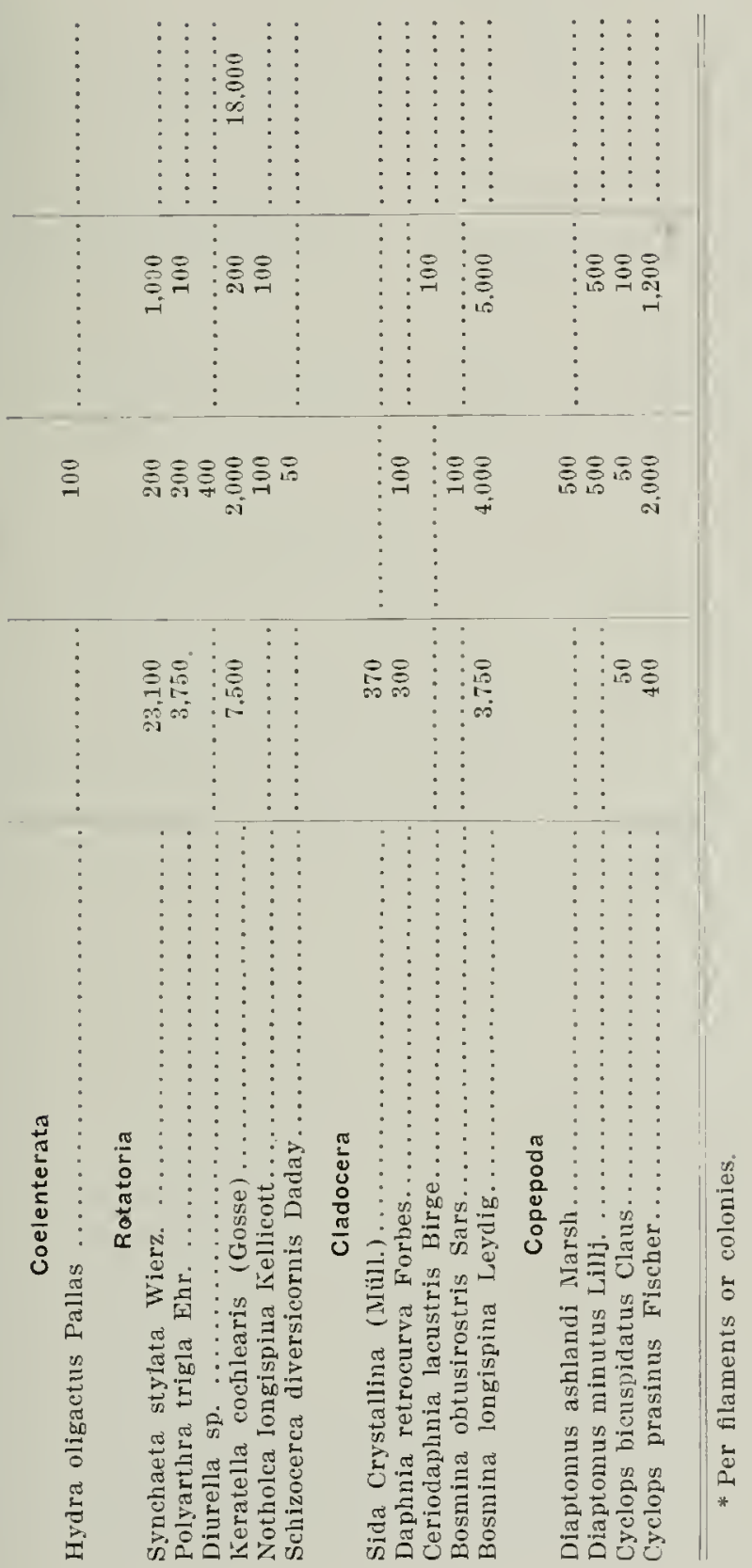




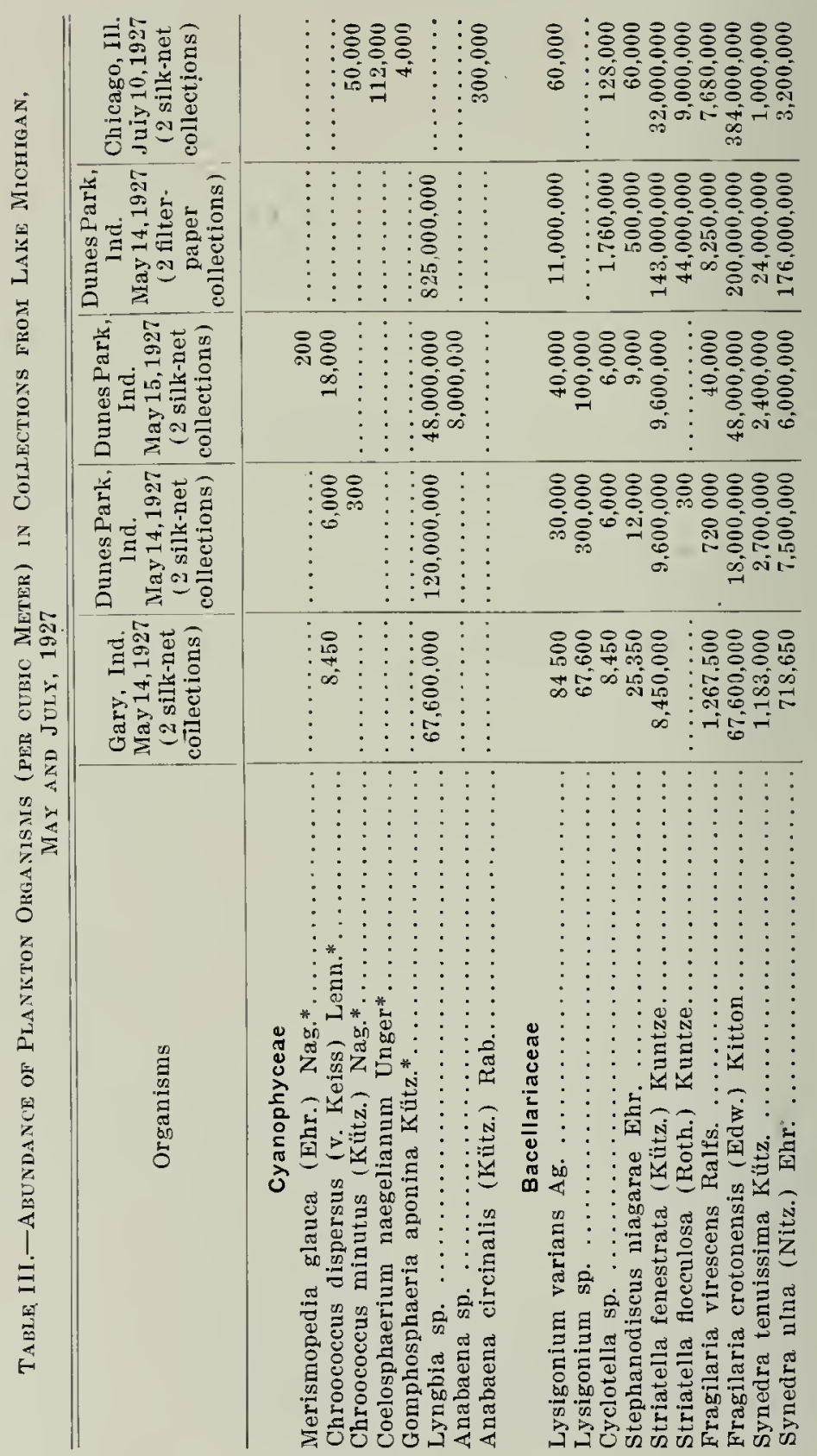




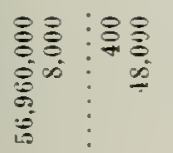

$\sum_{i=1}^{\infty} \oint_{i=}^{20}$

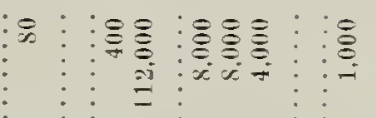

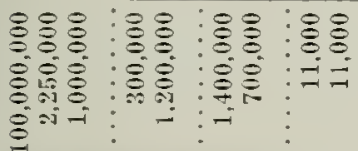

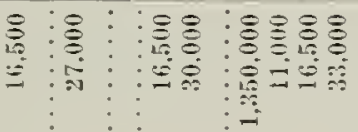

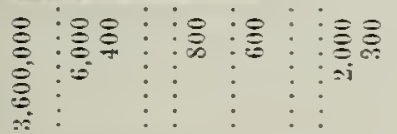

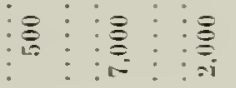

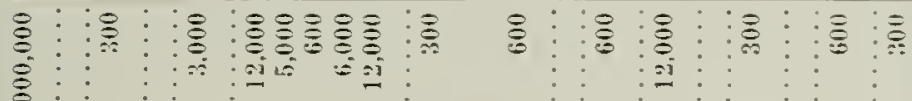

:

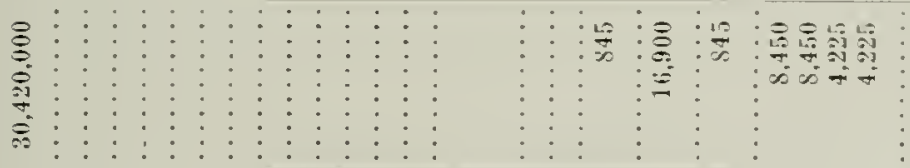

产

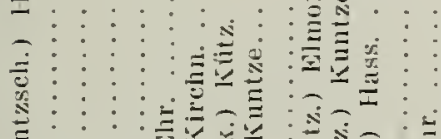

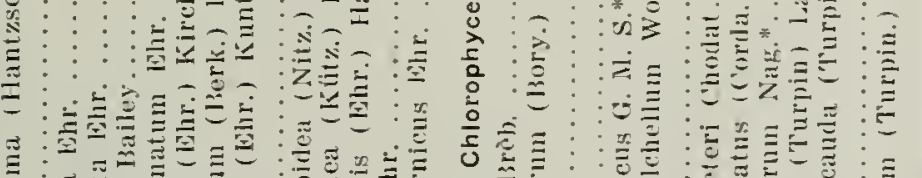

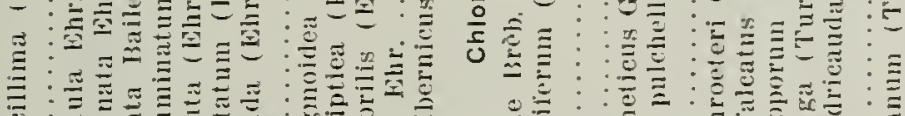

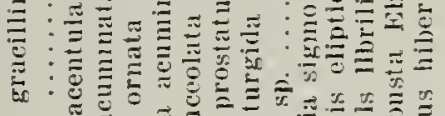

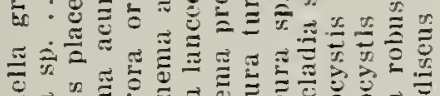

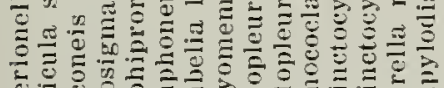

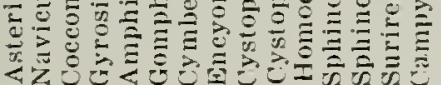

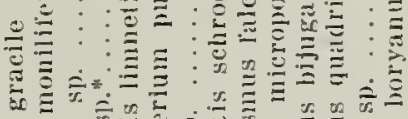

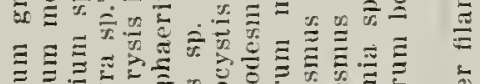

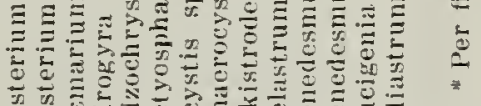

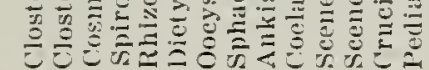




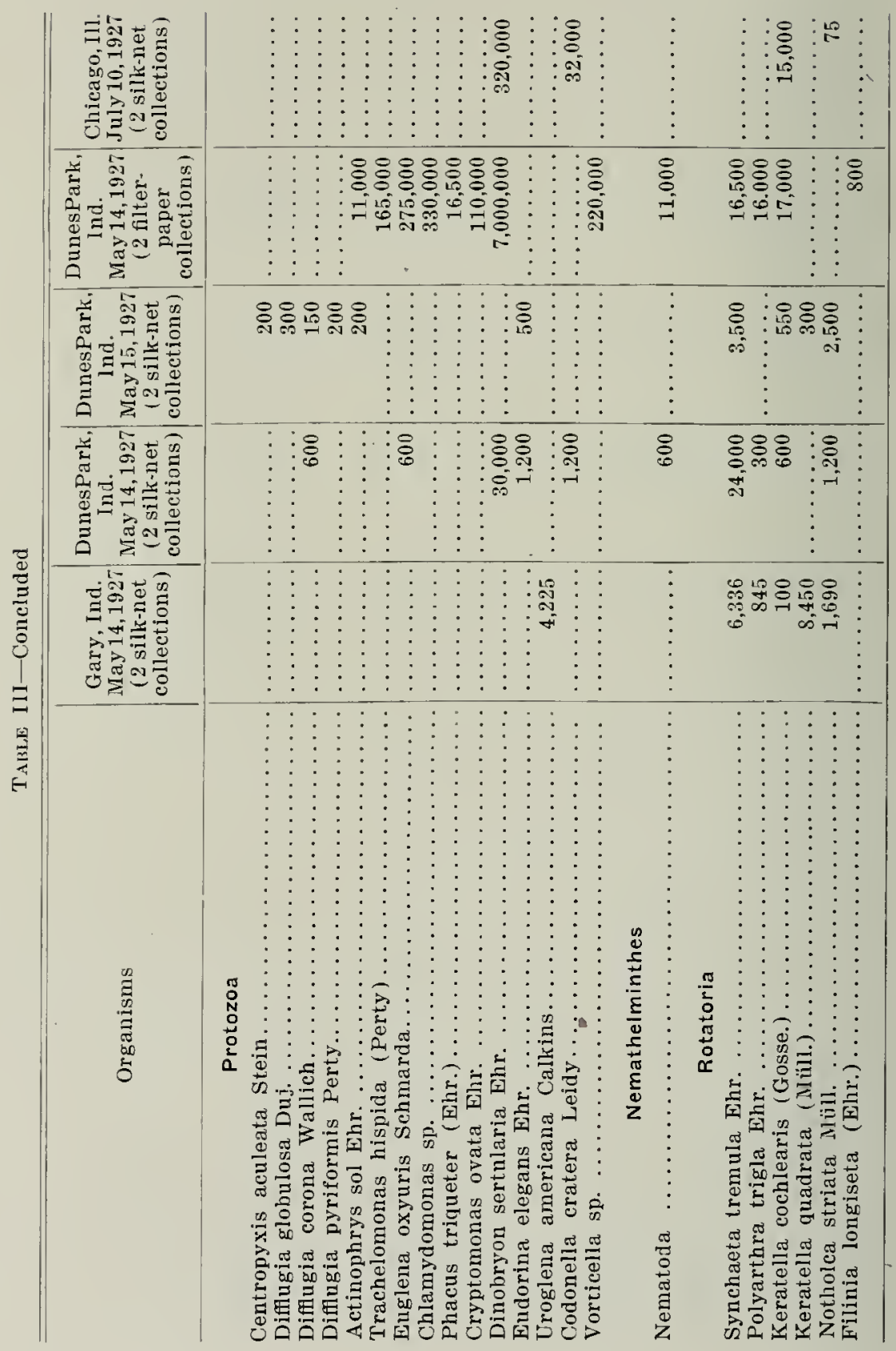


THE PLAXKTOY OF L.AKE MICHIGAN

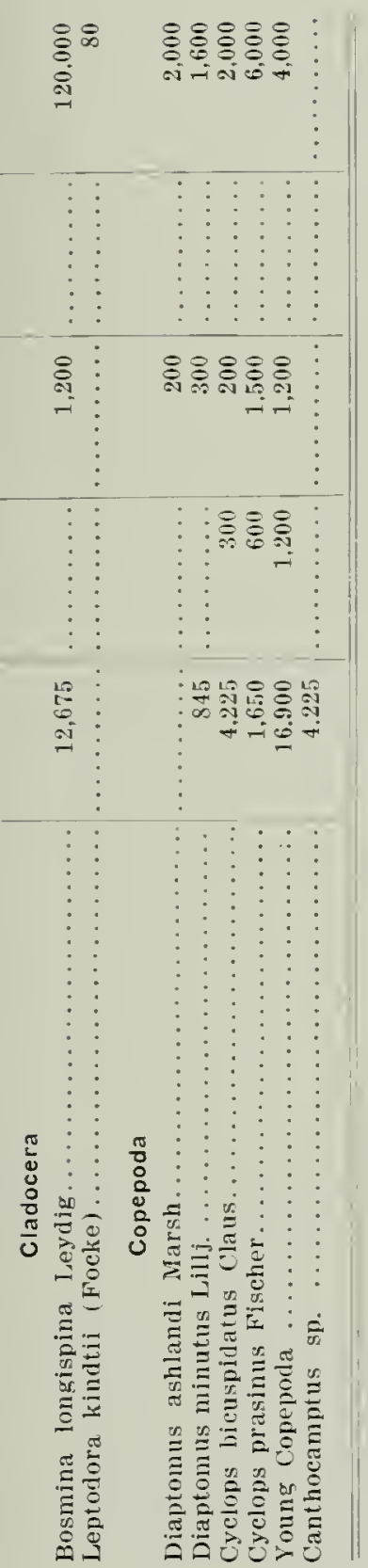




\section{NOTES ON CONSTITUENT ORGANISMS CYANOPHyCEAE (BLUE-gREen ALGAe)}

The blue-green algae, never very abundant in plankton collections of Lake Michigan, were represented by a few species which were usually present in small numbers in most of our collections. Fourteen species were noted in all. Snow (1902) listed thirty-four species from Lake Erie. Ward (1896) noted several species from the Traverse Bay region. Whipple (Leighton, 190\%) found three genera of blue-green algae in Lake Michigan at Chicago.

Merismopedia: Merismopcdia glauca (Ehr.) Nag. appeared in small quantities in the collections of June, 1888. Fragments of the plate-like colonies occurred in the plankton Oct. 17-18, 1926 at Dunes Park, Michigan City, and Sawyer, and May 15, 1927 at Dunes Park. The colonies were never very abundant, averaging about 200 per c. m., although 3,750 per c. m. were counted in the 1926 collection from Dunes Park. Snow found this species in Lake Erie. Ward recorded $\boldsymbol{M}$. convoluta Breb. at Traverse Bay.

Coelosphaerium: Coclosphaerium liutzingianum Nag. occurred in small numbers in the collections of Nov. 1887, Aug. and Sept. 1888, and Oct. 1926. The colonies reached a count of 90,000 per c. m. at Michigan City, Oct. 17, 1926 . The absence of this species in all the spring collections suggests that it is not a spring form. Because of its small size and relative scarcity, it appeared to be of no great importance. Colonies of C. nargclianum Unger were common $(112,000$ per c. m.) in the plankton July 10,1927 at Chicago. Snow recorded C. Kutzingianum Nag. and C. roscum Snow from Lake Erie.

Gomphosphaeria: Colonies of Gomphosphaeria aponina Kutz. occurred only sparingly (4,000 per c. m.) July 10, 1927 at Chicago. This species was reported from Lake Erie by Snow.

Aphanocapsa: Floating colonies of Aphanocapsa elachista W. \& G. S. We appeared only in the collections made in the fall of 1926, when they were quite common. Colonies of much smaller cells, A. delicatissima W. \& G. S. West, occurred at the same time but were never as abundant.

Aphanotheca: Colonies of an undetermined species belonging to this genus were quite common in the plankton collections in the lall of 1926.

Chroococcus: Three species of Chroococeus occurred in the recent collestions. Probably hecause of the small size of the colonies, none of this genus were found in the earlier collections. Colonies of $C$. dispersus (V. Keiss.) Lemm. were found occasionally in the 1926-1927 collections. C. minutus (Kutz.) $\mathrm{Nag}$. and $\mathrm{C}$. limneticus Lemm, occurred sparingly in the 1926 collections. Snow reported the latter species and also C. pallidus Ehr. and C. purpureus Snow from Lake Erie.

Anabaena: Filaments of a very sumall undetermined species of Anabcena occurred sparingly in some of the collections of Dec. 1887, Sept. 1888, Oct. 1888, Oct. 1926, and May 1927. It was never abundant and was probably lost through the meshes of the net in many of the collections. A. circinalis (Kutz.) Rab. was common (300,000 per c. m.) in the silk-net collections July 10, 1927 at Chicago. Snow reported this species from Lake Erie. Ward recorded $A$. flos-aquae $\mathrm{Kg}$. from the Traverse Bay region.

Lyngbia: An undetermined species of Lyngbia occurred abundautly in a!l the 1927 collections. This form was found sparingly in the collections of oct. 1888. Snow found $L$. wollei Farlow in Lake Erie. 
Oscillatoria: A few strands of Oscillutoria princelss Vaucher occurred in the collections of Oct. 1Sss. Snow recorded a number of species from Lake Erie but not this same species.

\section{BACELLARIACEAE (DIATOMS)}

Diatoms are the most abundant organisms in the plankton of Lake Michigan. Every collection contained them in large numbers. Twentysix sjecies, chiefly of four genera, were noted in all. Thomas and Chase (18nfi) collecied 215 species of cliatoms during a period of sixieen years from the water supply of Chicago, many of which undottbtedy were nol plankion diatons. Thompson ( Ward, 1s!li) found diatoms very alundant at Traverse Bay and listed fourteen species. Whipple (Leigh10n. 1!90) gave eight genera as heing conmon in Lake Michigan at Chicago.

Lysigonium (Melosira): Lysigonium varians Ag. was common in all the collections exanined. L. gramulata (Ehr.) Ralts, occurred occasionally, and a species of this genus resembling $L$, armuriu Moore was abundant in the october 1926 collections. Snow reported Velosiru arenariu Moore, $1 \%$. grunulatu (Ehr.) Ralfs., and $M$. variuns Ag. trom Lake Erie; hut neither Whipple nor Ward reported any species of this genus.

Cyclotella: A species of cyclotellu resembling C. mencyhiniunu Rabh. was common $(2,500-1,760,000$ per $c$. m.) in the collections of 1926 and 1927 . This small diatom occurred sparingiy in the 1s\$7-1Sss collections. Snow reported four species of Cyrlotelia. from Lake Erie. Ward listed C. opereulata $\mathrm{K}$. trom the Traverse Bay region. Whipple found this genus ahundant at Chicago.

Stephanodiscus: Strphanodiscus niagarae Ehr. occurred occasionally in most of the collections and was abundant in the 1927 collections, reaching a maximum of 500,000 per c. 11. in a filter-paper collection May 14, 1927 at Dunes Park. Snow found S. niagurar in Lake Erie. Ward reported this species from Traverse Bay, but Whipple listed it as absent from lake Iichigan at Chicago.

Striatella (Tabellaria): sitriatelle fenestratu (liutz.) liuntze was one of the most abundant organisms in the plankton. reaching a maximum of 143,000,000 per c. m. May 14, 1927 at Dunes Park. Every collection throughout the year of 1SS7-1SSS was filled with the zigzag chains of this diatom. s. focmllosa (Roth.) Kuntze was plentiful in most of the collections but never as abundant as א. fenestrata. Thompson found both species abundant in the Traverse Bay region, Snow reported them from Lake Erie, and Thomas and Chase found them in the Chicago water supply. Whipple listed this genus as abundant in Lake Michigan at Chicago.

Fragilaria: Frayilaria virescens Rales. and $F$. crotonensis (Edw.) Kitton were abundant at all times. The ribbon-like strands of these diatoms, together with strutella, symedra, and Astrrionclla. composed most of the plankion. The most abundant of all the organisms in the plankton was $F$. crotonensis, which reached a maximum of $384,000,000$ ner c. m. in a silk-net collection July 10 , 1927 at Chicago. Thompson reported $F$. capucina Desn. as very common in Traverse Bay. Snow listed $F^{\prime}$. crotonensis and $F$. virescens from Lalie Erie. Whipple found this genus only occasionally in Lake Michigan at Chicago. Chase and Thomas reported six species of this gellus, including $F$. virescens but not $l$. crotoncnsis, from the Chicago water supply. 
Synedra: Synedra ulna (Nitzsch.) Ehr. and Synedra tenuissima Elır. were abundant in all collections. S. ulna, one of the most abundant, reached a maximum of $176,000,000$ per c. m. May 14, 1927 at Dunes Park, while S. tenuissima, although never so abundant, reached a maximum of $24,000,000$ on the same date. Both species appeared to flourish more abundantly in the spring and late fall than in other seasons. Thompson reported S. ulna and S. affinis Kutz. in Traverse Bay. Snow reported $S$. ulua and $s$. oxyrhynchus Kg. from Lake Erie. Thomas and Chase listed fourteen species of this genus including $S$. ulna but not $s$. tcnuissima from the Chicago water supply.

Asterionella: Astcrionella gracillima (Hantzsch.) Heib., one of the most common diatoms, occurred in all collections except those of Jume and July, 1885. Its occurrence throughout the rest of the year suggests that it has a longer season of growth in Lake Michigan than in other nearby waters, possibly because of the lower temperatures of Lake Michigan. Kofoid (1908) reported this species as a spring form in Illinois River with a maximum abundance of $\$ 91,000,000$ per c. m. The greatest abundance observed in Lake Michigan was $100,000,000$ May 14, 1927 in a filter-paper collection at Dunes Park. Thompson reported A. formosa Hass. from Traverse Bay. Snow also listed A. formosa from Lake Erie. Whipple found Astcrionella to be the most abundant genus at Chicago. Chase and Thomas listed $A$. formosa from the Chicago water supply.

Navicula: Several undetermined species of Navienla occurred very sparingly in the collections of 1927. Diatoms of this genus never appeared in any quantity in any of the collections. Ward listed three species of Navicula from Traverse Bay, and Whipple found Navicula to be common at Chicago. Snow recorded three species from Lake Erie. Forty-nine species of this genus were listed by Thomas and Chase from the Chicago water supply, but many of them undoubtedly were not plankton species.

Cocconeis: Cocconeis placentula Ehr. was found rather sparingly May $18 s 8$ at Chicago and May $192 ?$ at Dunes Park. This species reached a maximum abundance of 100,000 per c. m. in the filter-paper collections. Snow recorded this species from Lake Erie. Ward found $C$.. transversalis Greg. in Traverse Bay. Thompson reported $C$. placentula as being dredged from the bottom of Trave se Bay. Thomas and Chase listed $C$. lineata $K$. and $C$. pecliculus Ehr. from the Chicago water supply.

Gyrosigma (Pleurosigma): Gyrosigma aeuminata (Kutz.) Cl. was found sparingly at Dunes Park, May 14, 1927, but was not observed in any other collections. G. attenuatum Sn. was reported by Snow from Lake Erie but was not among the six species of this genus listed by Thomas and Chase from the Chicago water supply.

Amphiprora: Amphiprora ornata Bailey occurred (300,000 per c. m.) in the filter-paper collections May 15, 1927 at Dunes Park and also $(48,000)$ in the silk-net collections July 10, 1927 at Chicago. A. alata (Ehr.) Kutz. was found sparingly in the collections made Oct. 17-18, 1926. These species lave not been reported by other workers in any of the Great Lakes except by Thomas and Cbase who reported $A$. calumetica Thomas and $A$. ornata from the Chicago water supply.

Gomphonema: Gomphoncma acuminatum Ehr., which occurred very sparingly in the silk-net collections at Dunes Park May 14, 1927, was quite common in the 1887-1S88 collections except during the months of June, July, and December. It usually appeared in swarms attached to floating debris. Snow reported this species and three others from Lake Erie." Thomas and Chase listed eighteen species including $G$. acuminatum from the Cbicago water supply. 
Cymbella: Cymbella lanccolata (Enr.) Kirchn. oceurred sparingly in the silk-net collections May 14-15, 1927 at Dunes Park but did not appear in any of the other collections. Snow reported C. marulata Kg. and C. rotundata H. H. C. from Lake Erie. Thompson found $C$. gastroilds to be common in the Traverse Bay region. Thomas and Cliase reported twelve species including C. lanceolata from the Chicago water supply.

Encyonema: Enryonema prostratum (Berk.) Kutz. occurred in the filterpaper collections $(1,400,000$ per c. M. May 14, 1927) at Dunes Park. This species appeared in collections of Nov. 1887 and Oct. 1888. appareut]y having Thomas and Chase found it and three others of this genus in the Chicago a tall and spring distribution. Snow reported this species from Lake Erie. water supply.

Cystopleura: Cystolloura turyida (Ehr.) Kuntze occurred frequently in the collections Hay 14-15, 1927 from Dunes Parli. An undetermined species of this genus also oceurred rather sparingly in the same collections. No species of this genus were observed in any other collections. Snow reported Cystopleura. (Epith(mia) turgida and three other s]ecies of this genus from Lalie Erie. Thomas and Chase Jisted six species of this genus including (r. turuia from the Chicago water supply.

Homoeocladia: Homoeocladia sigmoinca (Nitz.) Elmore was found sparingly in some of the collections May 14, 1927 from Dunes Park, but did not ap. pear in any of the other collections. Snow reported this species as Nitzschia sigmoidea (Nitzsch.) Su. and another species, N. lincaris Sm., from Lake Erie. Thompson recorded $\mathbf{N}$. siymoide from Traverse Bay. Whipple listed diatoms belonging to Nitzschin as being very abundaut at Chicago. Thomas and Chase found eleven species of this genus including $\mathcal{X}$. sigmoirlca in the Chicago water supply.

Sphinctccystis: Sphinetocystis eliptiea (kutz.) luntze occurred sparingiy in the 1926-1927 collections. It was found only once (in June) in the collections of 1888. S. librilis (Ellr,) Hass. was present in small numbers in most of the 18S7-18Ss collections, not appearing from Dec. to April, and in most of the 1926-1927 collections. Snow reported $s$. (cymatopleura) cliplica Sm. and s. sol'a Breb. from Lake Erie. Thomas and Chase listed five species of Cyma toplewro, including $C$. cliptica but not $C$. librilis. from the Chicago water supply.

Surirella: Surircll robusta Elı. occurred very sparingly (\$5 per c. in.) July 10,1927 at Chicago. Snow recorded three species of this genus but not this species from Lake Erie. Thomas and Chase listed 10 species of this genus but not robusta from Lake Michigan at Clicago.

Campylodiscus: Cammlorliscus hibrnicus Ehr. was tound in very small numbers in one silk-net collection from Dumes Park, May 14, 1927. Snow reported $C$. cribrosus Sm. from Lake Erie. Thomas and Chase Jisted C. nibrvicus and $C$. norieus Ehr. from the Chicago water supply.

\section{CHLOROPHYCEAE (GREEN ALGAE)}

The green algae were never abundant in the planliton of Lake Michigan. Twenly species, some of which were very rase, occurred in the collections. Mlany of the smaller species which occursed rarely in the recent series did not appear in the earlier series; this may have been due to the use of a coarser net through which most of the smaller forms were lost. Snow (1902) recorderl 1:6 species from Lake Erie. Thompson (Ward, 
18!6) reported that the green algae were almost entirely absent from the Traverse Bay region, as he found only a few species there. Whipple (Leighton, 190\%) listed seven genera as common in Lake Michigan at Chicago.

Closterium: Clostcrium gracilc Breb., which occurred sparingly in most of the recent collections, was not observed in any of the 1857-1585 collections. C. moniliferum (Bory) Ehr. occurred only in the July 1927 collections (80 per c. m.). Snow noted six species of this genns from Lake Erie but did not include gracile and monoliferum. Whipple reported closterium as occurring occasionally in Lake Nichigan at Chicago.

Spirogyra: Fragments of Spirogyra (several unidentified species) were found occasionally in the 1927 collections and in the collections of April and June 1888. This genus was not reported by Snow or Thompson, although it was noted by Whipple as "occasional" at Chicago especially around the water supply crib.

Cosmarium: An undetermined species of Cosmarium was found only in the filter-paper col'ections May 14, 1927 at Dunes Park (27,000 per c. m.). This species may have been lost through the meshes in the silk-net collections. Snow listed eleven species of Cosmarium from Lake Erie.

Chrysophaerella: Some colonies of green algae agreeing with ohrysophacrella longispina Lauterborn were quite common in the collections oct. 17-18, 1926 at Michigan City and Sawyer and Jnly 10,1927 at Chicago. This species did not appear in any of the other collections and was not reported from the Great Lakes by any of the previous investigators.

Dictyosphaerium: Colonies of Dictyosphaerium puchellum Wood were quite common in all of the 1926-1927 collections. The greatest abnndance recorded was 112,000 colonies per $c$. $m$. in a silk-net collection July 10,1927 at Chicago. This species occurred in small numbers in the collections of Angust 18s8. Snow reported $D$. puchellum and $D$. ehrenbergianum Nag. from Lake Erie.

Botryococcus: Colonies of Botryococcus sudeticus Lemm. occurred in small nnmbers in the collections of Oct. 17-18, 1926. Snow listed only B. braunii Kg. from Lake Erie.

Kirchneriella: A few species of Kirchneriella obesa Schmidle occurred sparingly (200 per c. m.) in the collections Oct. 15, 1926 from Michigan City. Snow reported this species and $K$. lunaris (Kirch.) Nob. from Lake Erie.

Oocystis: An undetermined species of oocystis occurred rarely in the collections, 200 per c. m. Oct. 18, 1926 at Sawyer and 30,000 per c. m. May 14, 1927 at Dunes Park. Snow reported three species of this genus from Lake Erie.

Sphaerocystis: A few colonies (\$45 per c. m.) of sphaerocystis schroctcri Chodat were found in a silk-net collection May 14, 1927 at Gary and also (7,000 per c. m.) Jnly 10,1927 at Chicago. This species has not been reported for the Great Lakes by any of the other investigators.

Ankistrodesmus: Ankistrodesmus falcatus (Corda.) Ralfs. was fonnd only in the collections of May 14-15, 1927 from Dnnes Park and July 10, 1927 from Chicago. Clusters of the crescent-shaped cells were quite abundant $(1,350,000$ per c. m.) in the filter-paper collections, showing that most of the cells passed through the silk net. This species was not mentioned by any of the previous investigators. 
Coelastrum: Two species of Coclastrum. were found in several of the collections. C. rrticulatum (Dangeard.) Senn. Was found occasionally in the collections of Oct. 17-18, 1926 and rarely in the collections of Sept. 1SSS. C. microporum Nag. was found in two silk-net collections, May 14, 1927 at Gary and July 10, 1927 at Chicago, and in a filter-paper collection, May 14, 1927 at Dunes Park. Snow reported four species of this genus, including these two, trom Lake Erie.

Tetrastrum: An undetermined species of Tetrastrum occurred in small numbers (200 per c. m.) in silk-llet collections Oct. 1S, 1926 at Sawyer. Species of this genus were not observed in any of the other collections. This genus has not been reported from the Great Lakes by any of the previous investigators.

Scenedesmus: Two species of scrnerssmus, which is a very common genus in small lakes and ponds, were found in the 1926-1927 collections. Because of their minute size, these species were probably lost in the earlier collections, and only a few were retained in the recent collections. s. bijuga (Turpin) Lag. occurred ( 8450 per c. m.) May 14,1927 at Gary and $(16,500$ per c. 1 .) in filterpaper collections of the same date at Dunes Park. š. quaricumda (Turpin) Breb. occurred in rather small numbers $(600-33,000$ per c. m.) Nay 14, 1927 at Gary and Dunes Park and Oct. 18, 19:6 at Sawyer. Snow reported ten species of this genus, including these two species, from Lake Erie. Whipple found this genus rather abundant at Chicago.

Crucigenia: A very small undetermined species of this genus occurred $(1,000-4,225$ per c. m.) in the silk-net collections from Gary and Chicago. This form did not appear in any of the other collections, nor was it mentioned by any of the earlier investigators.

Pediastrum: Although Pediastrum is quite a common plankton genus, it was never abundant in our collections. P. boryanum (Turpin) Menegh. occurred rarely in the Dec. 1857 and Aug. 1885 collections and appeared in small mumbers (100-7,000 per c. m.) Oct. 17-1S, 1926 and Nlay 14, 1927 at Dunes Park and July 10, 1927 at Chicago. P. simplix var, luolenarium (Bail.) Rab. occurred only in the silk-net collections Oet. 17, 1926 from Dunes Park and Micligan City. $p$. duplex Meyen. was present $(40-2,500$ per $c$. m.) in the collections if Oct. 17-18, 1926. Thompson reported only $P$. boryanum from Traverse Bay. Snow listed six species of this genus including these three in Lake Erie. Whipple found this genus to be common in the Chicago area.

\section{PROTOZOA}

Protozoa, because of their small size and relatively small abundance. were of little importance in the plankton, even in the warmer seasons when they were most numerous. The collections contained at least twenty-one species of protozoans, eleven of which seemed to he typical plankton forms. The others prolalily were washed up from the bottom or from the vegetation growing on piles and floating timbers. Smith (18.t) found ten species in the surface plankton of Lake St. Clair and a number of others from the vegetation and hottom. Fofoid (Ward, 1s!96) reported eigliteen species from the plankton of the Traverse Bay region, but no littoral species. Jennings $(1900)$ listerl twenty-two species as limnetic in Lake Erie. Whipple (Leighton, 190\%) listed nine genera as present in the waters of Jake Michigan at Chicago. 
Centropyxis: Centropyxis aculcata Stein occurred sparingly in the July 1888 collections and appeared in small numbers (200 per c. m.) Oct. 17, 1926 at Sawyer and May 15, 1927 at Dunes Park. This species was never abundant enough to form an important element of the plankton. Kofoid reported it from bottom tows in Traverse Ray.

Difflugia: Four species of Diffugia were found. D. globosa Duj., the most abundant of all the rhizopods, reached a unamum of 25,000 per c. 11 . in the autumn of 1926 but was rather rare ( 300 per c. m.) in the spring of 1927. This species was listed as abundant in Traverse Bay by Kofoid and in Lake St. Clair by Smith. D. lebes Penard appeared in small numbers in tlie Sept. and Oct. collections of 1888 . D. corona Wallich occurred only sparingly (150-600 per c. m.) May 14-15 at Dunes Park. Smith found this species in the shallow waters of Lake St. Clair. D. pyriform is Perty was found in very small numbers (200 per c. m.) May 15, 1927 at Dnnes Park. Kofoid reported this species as rare in the plankton of Traverse Bay.

Actinophrys: Actinophrys sol Elir. appeared iu small numbers (200 per c. m.) May 15, 1927 at Dunes Park. Kofoid reported this species as adventitious in the plankton of 1llinois River. Smith found this species in small numbers in the surface tows from Lake St. Clair.

Trachelomonas: Trachelomonas hispida Perty was found abundantly $(165,000$ per c. m.) in the filter-paper collections May 14, 1927 from Dunes Park. This species and others of this genus may have been abundant in the plankton when the older series of collections were made, but because of their size they probably escaped or were impossible to identify in the preserved material. Landacre (1908) reported tbis species from Sandusky Bay.

Euglena: Euglena oxyuris Schmarda occurred frequently May 14, 1927 at Dunes Park, reaching a maximum of 275,000 per c. m. in the filter-paper collections. E. viridis, which was reported by both Jennings and Landacre from Lake Erie, was not identified in any of the collections examined.

Chlamydomonas: An undetermined species of Chlamydomonas was found abundantly (330,000 per c. m.) in the filter-paper collections May 14, 1927. This form did not appear in any of the other collections, probably escaping through the meshes of the silk net. Snow (1902) listed three species of this genus from Lake Erie.

Phacus: Phacus triqueter Ehr. occurred occasionally (16,500 per c. m.) in the filter-japer collections May 14, 1927. This species was not found in any of the silk-net collections. In Lake Erie Jennings reported it from East Harbor, and Landacre listed it from Sandusky Bay.

Cryptomonas: Cryptomonas ovata. Ehr. was found in the filter-paper collections (110,000 per c. m.) May 14, 1927 at Dunes Park. This form was observed only in fresh living material, and probably because of its ninute size it did not appear in the silk-net collections. Whipple reported this genus as present at Chicago.

Eudorina: Eudorina elegans Ehr. was found in small numbers (200-1200 per c. m.) in 1926 and 1927 . This colonial flagellate has not been reported by previous investigators from the Great Lakes. Kofoid found the closely related form Pandorin morum Bory de. St. Vincent in Traverse Bay.

Uroglena: Colonies of Lroglena americana Calkins occurred occasionally in two recent collections. Lofoid reported $U$. volvox Elur. as common in the form Pandorin morum Bory de St. Vincent in Traverse Bay. 
Dinobryon: Dinobryon sertularia. Elnr. was the most abundant protozoan in the plankton. This species seemed to have a swarning tendency, for it was found abundantly in some collections only to be almost absent from others of the same date and place. It was present also in small numbers in the Sept. 1888 collections. In those of Oct. 1926 it reached an abundance of 900,000 per c. $\mathrm{m}$., and in the filter-paper collections of May 14, 1927 it reached an abundance of $7,000,000$ per c. ni. liofoid found this species to be abundant in the Traverse Bay region. Smith reported it as abundant in Lake St. Clair, and Whipple lister it as plentiful in Lalie Michigan at Chicago.

Ceratium: Ceratium hirmalinclla Miijl. Was common in the collections of Oct. 1926, and occurred in mall mumbers in those of Aug. and Sejt. 18s8. Kofoid found this species abundant in the Traverse Bay region, and Smith also found it numerous in the surface tows of Lake St. C'air.

Peridinium: Perialinium tubulatum Ehr. occurred occasionally in the collections of Aug. $188 S$ but did not appear in any of the others. As this is a common species in other waters, its apparent scarcity in our collections may bc due to its snall size and consequent loss through the meshes of the silk net. Fofoid found $P$. tabulatum common in the summer at Traverse Bay, Snith listed it as scarce in Lake St. Clair, and Jennings recorded it from several parts of Lake Erie. Whipple listed this genus as fairly common in July at Chicago.

Codonella: Colonclia cratru Leidy occurred in small numbers in the collections of July, Aug. and Sept. 1 SSS and in some of the 1926-1927 collections reaching a maximum abundance of 32,000 per c. $m$. in a silk-net collection July 10, 1927 from Chicago. This small-shelled ciliate was reported by Kofoid as abundant in the Traverse Bay region. Smith found it abundant in the plaukton of Lake St. Clair and Jennings listed it from lake Erie.

Vorticella: One or more undetermined species of Torticella occurred occasionally in the collections of Sept. and Oct. 1SSS. They were found in consider able numbers $(220,000$ per c. m.) attached to floating debris and diatoms in the filter-paper collections May 14, 1927 at Dunes Park. Kotoid l'ound Vorticclla in the plankton of the Traverse Bay region. Smith recorded this genus as abundant on diatoms in Lake St. Clair. Jennings found T. rhubdostyloides Kelli. cott common in Lake Erie. Whipple listed this genus as common in Lake Michiigan at Chicago.

Thuricola: A few specimens of an undetermined species of Thuricolo were found attached to floating debris in a collection of Sept. 18ss. This form was adventitious in the plankton, belonging more properly to the shore and hottom. Smith found closely related forms to be scarce anong the algae in the shallow waters of Lake St. Clair.

Podophrya: An undetermined species of this gelus occurred attaclied to floating debris in a Selut. $188 S$ collection. Smith reported $P$. cyclopum C. \& L. on algae in Lake St. Clair. The same species was found rarely by Kofoid attached to Epischurl lacustris Forbes in the Traverse Bay region.

Acineta: Severa] undetermined species of Acincta were found attached to algae in the collections of Sept. 1sss. Jennings reported finding A. mystacina Ehr. attached to floating material in Lake Erie.

\section{COELENTERATA}

Several species of Hydra are the only coulenterates known to occur in the Great Iakes. Hydra oligactus Pallas was found sparingly (100 per c. m.) in a silk-net collection Oct. $1 \%, 1926$ from Micliggan City. It 
occurred in small numbers in the December $188 \mathrm{r}$ and the September 1888 collections. Welch and Loomis (1924) reported the occurrence of Hydra in great abundance in Lake Erie and in Lake Michigan near Michigan City, Indiana.

\section{NEMATHELIMINTHES}

Free-living nematodes are predominately bottom forms in Lake Michigan. A few undetermined nematodes were found in the collections May 14, 1926 from Dunes Park. These were probably bottom forms washed up from the shallow waters by wave action.

\section{ROTATORIA}

Sixteen species of rotifers were found in the plankiton of Lake Michigan, although none of then werc ever very abundant. These species were all typical plankiton forms, several of them being distributed through most of the collections. The rotifers of the Great Lakes as a gro'ip have been thoroughly studied by several investigators. Kellicott (1S!9, 189\%) published a long list of the rotifers of Lake Erie in the region of Sandusky Bay, including both bottom, shore, and limnetic forms. Jemnings (189t) reported twenty-four limnetic species occurring in Lake St. Clair and referred to the distribution of many species in Lake Erie. In a later and more complete survey covering most of the rotifers of the United States. Jennings $(1900,1902)$ gave a list of twelve species as occurring in the plankiton of Lake Erie and listed seven other species as occurring in the plankton of others of the Great Lakes. Jennings (Ward 1896) found the rotifers less abundant in the Traverse Bay region than in Lake St. Clair; he reported the limnetic forms in the Traverse Bay region to be well represented and listed fourtecn limnetic and eight bottom species.

Synchaeta: Two species of syncharta occurred in our collections, S. styiata Wierzejski on Oct. 17-18, 1926 and S. tremula Müll. on May 14-15, 1927. No species of this genus were found in the earlier collections; they may have been present but overlooked, as this genus is sometimes very hard to identify in ordinarily preserved collections. S. tremula was donbtfnlly reported by Kellicott from a marsh near Lake Erie. Kellicott found S. stylata and S. pectinata Ehr. abundantly in Sandusky Bay. Jennings reported $S$. styiata as present in Traverse Bay, rare in Lake Erie, and one of the most abundant species in Lake St. Clair. Whipple listed this genus as present in Lake Michigan at Chicago.

Polyarthra: Polyarthra trigla Ehr. (P. platyptera Ehr.) was found in small numbers in the May, July, and Sept. collections of 1888 . This species also occurred in the collections of Oct. 1926 and May and Jnly 1927, ranging from 100 to 16,000 per c. $m$. Jennings found this species abundant in Lake Erie and reported it for the Traverse Bay region. Whipple listed it as present in Lake Michigan at Chicago.

Diurella: Snall numbers (400 per c. m.) of an undetermined species of Diurella were found Oct. 17, 1926 at Michigan City. Jennings found many species of this genus in Lake Erie. 
Trichocerca: A few specimens of Trichoerrea cylmatica (Imhof) (Rattulus cylindrice Imhof) occurred in one of the September $18 s 8$ collections. Jennings found many species of this genus including Rattulus cylindricus Jennings present in Lake Erie.

Lepadella: Lepudrlla oblonga (Ehr.) (Mctopislia lrpalclla Levander) Was found rarely only in the July $1 S S S$ collections. This is not a typical limmetic species but probably a migrant from the bottom. Fellicott reported this species from Sandusky Bay. Jennings found it in Lake St. Clair and also in swamps about Lake Erie.

Trichotria: Trichotrin tetractis (Ehr.) (Dinocharis tefractis Elır.) was found sparingly in one of the July $188 S$ collections. This species is probably a migrant from the bottom, as Jemnings listed it from the bottom vegetation of Lake Erie and Lake St. Clail.

Keratella: Feretelle (Aumure) corhlearis (Gosse) which was found oceasionally in the May, July, Aug., Sept., and Oct. collections of 1 Ss was relatively. abundant in all the 1926-1927 collections, reaching a maximum of 17.000 per c. $\mathrm{n}$. in the filter-paper collections of May 14, 1927 from Dunes Park. $\pi$. quadrath. (Miill.) (A. aculcate Ehr.) was found (300-8,450 per c. m.) in several of the 1927 collections and nore rarely in the July $18 S$ s collections. Jennings found $K$. cochleuris and $K$. quelratu abundant in Lake Exie, Lake Michigan, and Lake St. Clair. $\pi$. cochloris was reported by Vorce (1SS1) from Lalie Erie and by kellicott from Sandusky Bay, as also was A. stipitatu Eir. Jemings reported A. surulutu Ehr. from Lake St. Clair. Whipple listed this genus as common at Chicago.

Notholca: Notholca longispina Kellicolt was characteristic of most of the plankton collections, appearing in all except those of Dec. 1857, April 188s, and May and July 1927. Jennings found it in Lake St. Clair and in Lake Michigan. N. striatu Müll. ( $N$. a umimat $\mathrm{H}$. \& G.) occurred sparingly in ou collections of July 1 S8S and May and July 1927. Forbes (18S3) mentioned this species as occurring in the plankton of Lake Michigan at Chicago.

Brachionus: Only a single species of this common plankton genus was found in our collections, a single specinen of Brachionus rapsuliflorus Pallas occurring in an Aug. 1SSS collection. Fellicott reported two suecjes of this genus, but not including this species, trom Sandusliy lBay. Jennings found this species and Brachinous militaris Elnr. abundant in the shallow parts of Lake Erie.

Schizocerca: A very few (50 jes c. m.) specimens of schizorerea diversicornis Daday were found Oct, 17,1926 at Michigan City. This sl:ecies, which is more typical of small sha! low lakes, has not been reported from the Great Lakes by previous investigators.

Asplanchna: Asplameluna priolontu Gosse was found occasionally in the Aug. collections of $18 S 8$. Kellicott found this species abundant and $t$. hrrickil de Guerne rare in Sandusky Bay. Jemnings reported A. priodonte from the plankton of Lake Michigan and Iake Erie.

Filinia: Filinin (Triathra) longisctu (Wlur.) occurred sparingly (\$00 per c. m.) at Chicago, Iuly 10, 1927. Fellicott found this species abundant in Sandusky Bay.

Conochiloides: Conochiloides dossuuris (Hudson) was found in small numbers in the Aug. $18 s 5$ collections. This species Was reported from Lake Erie by Kellicott, but not in any other of the Great Lakes by other workers. The 
closely related form C. hippocrcpis (Schrank) (C. volvox Ehr.) has been reported from Lake St. Clair by Jennings and from Lake Erie by Kellicott. Another similar form $C$, unicornis Rousselet was common in tows from Lake Erie (Jeunings) (Kellicott) and from Lake St. Clair (Jenniugs).

\section{CLADOCERA}

Eleven species of cladocerans occurred in our collections. Their relative abundance was greater in the older series than in the recent series, undoubtedly because of the type of net used for collecting. Two species, Daphinia retrocura Forbes and Bosmina longispina. Leydig, seemed to be generally typical of the plankton, as they occurred in most of the collections. Snith (18:1) reported two species from Lake Superior. Birge (Reighard, 1894) found four species in the plankton of Lake St. Clair. Ward (1896) stated that the Cladocera formed an important element of the fauna of Iake Michigan in the Traverse Bay region; he found 25 or 30 species in this region but did not state how many of them belonged to the plankton. Whipple reported finding only one genus in the plankton of Lake Michigan at Chicago. Nine species of Cladocera were listed by Birge (1881) from the Chicago Water Supply, nine species by Sars (1916) from the Georgian Bay region, and twenty-seven species by Bigelow (1922) from Lake Ontario, Lake Erie, and Georgian Bay.

Sida: Siala crystallina (Miill.) occurred rarely in the Sept. 1888 collections and also ( 370 per c. m.) Oct. 17, 1926 at Dunes Park. Forbes tound this species occasionally in Lal e Superior. Birge found it abundant in Lake St. Clair. Sars and Bigelow both reported it from Georgian Bay. Bigelow found it fairly common in the shallow parts of Lake Erie.

Diaphanosoma: Diaphanosoma leuchtenbergianum Fiseher was occasional in the Sept. 1888 collections, but was common in the Oct. 1888 collections. Bigelow found $D$. brachyurum (Lièven) fairly common in Georgian Bay and Lake Erie. He reported that $D$. leuchtenbergianum was not as common in the waters of Georgian Bay.

Daphnia: Daphnia retrocurva Forbes occurred in nearly all the collections except those of 1927, running nearly througlout the year in the 1887-1888 collections. Because of its large size, it seemed to be quite common (100-300 per c. n.) D. longispina (Leydig) occurred in small numbers in the collections of Nov. 1887 and July and Sept. 18SS. The species of Daphnia reported from the Great Lakes by the early investigators are rather confused, because of the use of synonyms and European specific names. Smith reported D. galeata Sars and ij. pellucida Müll. from Lake Superior. Forbes (1881) reported D. longisqina var. hyatina Leydig from Lake Michigan, and later (1887) he reported $D$. retrocurva from Lake Superior. Birge listed $D$. kahlbergicnsis var. intexta Forbes and $D$. retrocurva from Lake St. Clair. Whipple reported this genus as occurring in Lake Michigan at Chicago. Sars found D. retrocurva in Georgian Bay. Bige'ow reported D. pulex (de Geer), D. retrocurva, and D. longispina from Lake Erie and Lake Antario.

Ceriodaphnia: Ceriodaphnia lacustris Birge occurred in small numbers ( 100 per c. $\mathrm{m}$.) in the Sawyer collections only. Sars found C. scitula Forbes in the plankton of Georgian Bay. Bigelow reported four species of this genus from Georgian Bay, including $C$. lacustris as "uncommon." 
Bosmina: Bosmina longispina Leydig. the most ahundant cladoceran o: Lake Michigan. Was one of the conspicuous organisus of the plankton. It was common in nearly all the collections, being entirely absent only from those of Dec. 185S, and reached a maximum of 120.000 per c. 11 . July 10. 1927 at Chicago. Birge reported this species as abundant in Lake St. Clair. B. outusirostris Sars. which has not been reported previously from the Great Lalies. occurred (1i) per c. m.) Oct. 17, 1926 at Dunes Park. B. longirostris (1lüll.) occurred rarely from April until Nov. in the $1 S S S$ collections. This species was found occasionally by Forhes in the plankton of Lake Superior. Sars and Bigelow both reported this species from Georgian Bay. and Bigelow also found it in Lake Erie.

Alona: An undetermined species of flond was found once in a collection of Aug. 1Sss. Forbes reported an undetermined species of this genus from Lake Superior. Birge found four species of Alona in Lake St. Clair. Bigelow found -1. affinis (Leydig) abundantly in the plankton from shallow waters of Georgian Bay.

Chydorus: Chydorus sphacricus (Müll.) occurred occasionally July 1Sss and rarely Sept. 1SSS bnt was not found in any of the 1926-19:-1 collections. Forbes found $C$. spharriens and C. gibuns Lillj to be common in Lake Superior. Birge reported C. sphafricus and C. ylobosus Baird in Lake St. Clair. Bigelow found three species of this genus, including C. sphuericus. in Georgian Bay.

Leptodora: Leptortor kindtii (Focke) occurred occasionally in the collec. ticns of Oct. 1SSS and July 1927. This large form was reported by Forbes as occasional in Lake Superior and in Lake IIchigan. by Birge as occasional in Lake Michigan and in Lake St. Clair, by Sars as common in Georgian Bay. and by Bigelow as common in Georgian Bay and in Lake Erie.

\section{COPEPODA}

Nine species of copepods, all trpical linnetic iorms. were fomd. three of them occtrring in a majority of the collections. Like the cladocerans. they were more abundant in the earlier collections than in the recent. smith (1nil) mentionet the occurtence of several species of copepods in Lake superior but dicl not lesignate the specie- or indicate their abnudance. Forbes (1si?) tound four specie- abundant in Lake $1 /$ iehigan. and in Lake superiur (18si) he found nime species. most of which were conmon. ( Marsh ( leta) found nine species of copepods in the plankton of the Traverse Bar region which were the same as those of the other Great Lakes: he reported six species from Lake Erie, nine species from Lake Michigan, and sixteen species from the plankton of lake St. Clair.

Epischura: Epischura lacustris Forbes occurrea quite abundantly in all the early collections except those of Dec. 1sS and July 1sss. For some un. known reason this species, which because of its abundance and large size was very prominent in the earlier series. did not appear at all in the recent series. Forbes found this species abundant in Lake Michigan at Chicago and Traverse Bay and also in Lal.e Superior. Marsh reported it as common in Lake St. Clair. Lake Erie, and Lake Michigan.

Diaptomus: Three species of Diaptomus were found in our collections. D. mimutu. Lillj. was common in the collections of Nov.. July. Aug.. Sept.. and Oct. 1857-1858, and in those of 1926-192\%. This species was quite conspicuous, ranging in abundance from 300 to 1600 per c.m. D. ashlondi Marsh was found 1200. 2.000 per c. n.) in 1926-1927. Marsh found both species in Lake Michigan and 
Lake St. Clair and reported $C$. minutus as the most common copepod in the Great Lakes. D. sicilis Forbes occurred occasionally in the Jume, Aug., and Sept. collections of 1888. Forbes found this species abundant in Lake Michigan and in Lake Superior. Marsh found it common in both Lake Michigan and Lake St. Clair. Marsh also reported $D$. orcgoncnsis Lillj. as occurring occasionally in Lake Michigan and in Lake Erie.

Limnocalanus: Limnoralanus macrurus Sars was found occasionally in the collections of Sept. 1888. Forbes found this species abundant in Lake Michigan at Chicago and aIso in Lake Superior. Marsli reported it from Lake Michigan and Lake St. Clair.

Cyclops: Three species of Cycloys occurred in our collections from Lake Michigan. C. bicuspidatus Claus was the most abundant, occurring in all the collections except those of Dec. 1887 and June 188s. This species was reported by Forbes as abundant in Lake Michigan and Lake Superior. Marsh mentioned it as the common Cyclops of the Great Lakes occurring in Lake Michigan. Lake St. Clair, and in Lake Erie. C. prasinus Fischer was abundant in the 1926-1927 collections and was fairly common in all tlie 1857-1885 collections except those of Dec., June, and July. Marsl (Ward and Whipple, 1918) stated that this species was common in the Great Lakes. C: fimbriatus Fischer was tound occasionally in the July, Aug., Sept., and Oct. collections of 188s. This species was not mentioned, at least not under this name, by any of the previous investigators. A total of fourteen species have been reported from the Great Lakes by previous investigators, but many of these are syuonyms.

Canthocamptus: An undetermined species of Canthocamptus occurred (4,225 per c. m.) in the collections of May 14, 1927 from Gary. Forbes found this genus to be rare in Lake Superior and Lake Michigan.

\section{SUMMARY}

The uniformity of the plankton from year to year and from season to season strikingly demonstrates the stability of Lake Michigan as a fresh-water habitat. Comparisons of recent collections with those made forty years ago show that very little change has occurred in the general composition of the plankton and justify the inference that there have been no changes in temperature, currents, depth, and chemical composition of the water sufficient to influence the production of plankton. Of the species which were abundant in the $188 \%-1888$ collections, only one, Epischura lacustris Forbes, was absent in the recent series. From the examination of the seasonal collections, there appeared to be a fairly constant and uniform phytoplankton throughout the year, although the zooplankton showed some response to seasonal conditions. Diatoms predominate at all times and constitute the majority of the organisms of the plankton, the same species being conspicuous in all the collections ex. amined.

\section{ACKNOWLEDGMENT}

The writer wishes to thank Mr. R. E. Richardson and Mr. H. C. Oesterling, both of the Illinois State Natural History Survey, for nuch valuable criticism and assistance in preparing this paper. 
BIGLLOW, N. K.

\section{BIBLIOGRAPHY}

1922. Representative Cladocera of South-Western Ontario. Lniv. Toronto Biol. Series 20: 111-125.

BuRGE, E. A.

1881. Notes on Crustacea in Chicago water supply. Holichl Jour, and Examiner 14: $5 \$ 4-590$.

BRIGGs, S. A.

1872. The Diatomaceae of Lake Michigan. The Lens, Chigago, 1: 41.

COOLES, L. E.

1913. The diversion of the waters of the Great Lakes by way of the sanitary and ship canal of Chicago. Pub. by The Sanitary District of Chicago. $216 \mathrm{pp}$.

FonBes, S. A.

1852. On some Entomostraca of Lake Michigan and adjacent waters. $4 \mathrm{~m}$. Nat. 16: $537-542,640-650$.

1883. The first food of the common white-fish. Bull. Ill. Nlate Lab. Yat. Hist. 1: 88-99.

1857. On some Lake Superior Entomostraca. Rept. $T$. S. Comm. Fish and Fisheries. 1S87, pp. 701-71s.

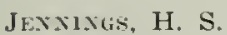

1594. A list of the Rotatoria of the Great Lakes. Bull. Hich. Fish Comm. 3. $34 \mathrm{pp}$.

1900. A report of work on the Protozoa of Lake Erie with especial refer. ence to the laws of their movements. Bull. $C$. N. Fish comm. 19: $105-114$.

1900. Rotatoria of the United States with especial reference to those of the Great Lakes. Bull. $\mathscr{C}$. S. Fish Comm. 19: 67-104.

1902. Rotatoria of the [inited States. 11. A monograph of the Rattulidar. Bull. L. S. Fish Comm. 22: 275-349.

KELLIVOTT, D. S

1896. The Rotifera of Sandusky bay. Proc. Am. Micr. Noc. 1s: 155-164.

1897. The Rotifera of Sandusky Bay (Second Paper). Proc. Am. Micr. SOC. 19: $43-54$.

Korolv, C. A.

190S. The Plankton of the Illinois River, 1894-1899. Part II. Constituent Organisms and their Seasonal Distribution. Bull. Ill. state Lab. Nat. II ist. S. $360 \mathrm{pp}$.

L.XIM-RE, F. L.

1908. The Protozoa of Sandusky Bay and vicinity. Proc. Onio Acad. sici. 4, Part 10.

LEIGHTON, M. O

1907. Pollution of the Illinois and Mississippi Rivers by Chicago sewage. U. S. Geol. Surv. Hater supply Paper 194. 369 pp.

MARsit, C. D.

1894. On the Cyclopidae and Calanidae of Lake St. Clair Bull. Mich. Fish comm. 5. 24 pp. 
Pueters, A. J.

1901. The plants of western Lake Erie. Bull. U. S. Fish Comm. 21: 57-79.

REIGIIARD, J. E.

1894. A hiological examination of Lake St. Clair. Bull. Mich. Fish. Comm. 4. $60 \mathrm{pp}$.

S.tis, G. O.

1916. Entomostraca of Georgian Bay. In Contr. Canad. Biol. 1911-1914. Suppl. 47th Anu. Rept. Dept Marine and Fisheries, Fisheries Branch, Ottawa. p. 221.

SMITH, S. I.

1S74. Sketch of the invertebrate fauna of Lake Superior. Rept. U. S. Fish Comm. 1872-1873, pp. 690-707.

Sxow, J. W.

1902. The plankton algae of Lake Erie with special reference to the Chlorophyceae. Bull. U. S. Fish Comm. 22: 371-394.

Thom As, B. W. and CHASE, H. H.

1887. Diatomaceae of Lake Michigan as collected during the last sixteen years from the water supply of the City of Chicago. Notar. Ann. 2: 328 .

VorCE, C. M.

1850. Some Ohservations on the minute Forms of Life in the Waters of the Lakes. Cleveland, $\mathrm{O}$.

1881. Forms observed in water of Lake Erie. Proc. Am. Micr. Soc. 4th Ann. Meeting. pp. 50-60.

1882. Microscopical forms observed in the waters of Lake Erie. Proc. Am. Nicr. Soc. 5th Ann. Meeting, pp. 187-196.

WALTON, L. B.

1915. A review of described species of the order Euglenoidina Bloch. Ohio State Univ. Bull. 19: 343-459.

WARD, H. B.

1896. A biological examination of Lake Michigan in the Traverse Bay region. Bull. Mich. Fish Comm. 6. $100 \mathrm{pp}$.

WARD, H. B, and Winpple, G. C.

1918. Fresh water biology. John Wiley and Sons, New York. 111 pp.

WELCH, P. S. and Loomis, H. A.

1924. Hydra oligactis in Donglas Lake, Michigan. Trans. Am. Micr. Soc. 43: $203-235$. 